\title{
Coupling of marine and continental oxygen isotope records during the Eocene-Oligocene transition
}

\section{Sheldon, ND}

http://hdl.handle.net/10026.1/5360

\subsection{0/B31315.1}

Geological Society of America Bulletin

Geological Society of America

All content in PEARL is protected by copyright law. Author manuscripts are made available in accordance with publisher policies. Please cite only the published version using the details provided on the item record or document. In the absence of an open licence (e.g. Creative Commons), permissions for further reuse of content should be sought from the publisher or author. 


\title{
Coupling of marine and continental oxygen isotope records during the Eocene-Oligocene transition
}

\author{
Nathan D. Sheldon', ${ }^{1,}$, Stephen T. Grimes ${ }^{2}$, Jerry J. Hooker ${ }^{3}$, Margaret E. Collinson ${ }^{4}$, Melanie J. Bugler ${ }^{2}$, \\ Michael T. Hren ${ }^{5}$, Gregory D. Price ${ }^{2}$, and Paul A. Sutton ${ }^{2}$ \\ ${ }^{1}$ Department of Earth and Environmental Sciences, University of Michigan, Ann Arbor, Michigan 48109, USA \\ ${ }^{2}$ School of Geography, Earth \& Environmental Sciences, Plymouth University, Drake Circus, Plymouth, Devon, PL4 8AA, UK \\ ${ }^{3}$ Department of Earth Sciences, Natural History Museum, Cromwell Road, London, SW7 5BD, UK \\ ${ }^{4}$ Department of Earth Sciences, Royal Holloway University of London, Egham, Surrey, TW20 OEX, UK \\ ${ }^{5}$ Department of Chemistry, University of Connecticut, Storrs, Connecticut 06269, USA
}

\section{ABSTRACT}

While marine records of the Eocene-Oligocene transition indicate a generally coherent response to global cooling and the growth of continental ice on Antarctica, continental records indicate substantial spatial variability. Marine Eocene-Oligocene transition records are marked by an $\sim \mathbf{+ 1 . 1 \%}$ foraminiferal $\delta^{18} O$ shift, but continental records rarely record the same geochemical signature, making both correlation and linking of causal mechanisms between marine and continental records challenging. Here, a new high-resolution continental $\delta^{18} O$ record, derived from the freshwater gill-breathing gastropod Viviparus lentus, is presented from the Hampshire Basin, UK. The Solent Group records marine incursions and has an established magnetostratigraphy, making it possible to correlate the succession directly with marine records. The $V$. lentus $\delta^{18} \mathrm{O}$ record indicates a penecontemporaneous, higher-magnitude shift $(>+1.4 \%$ ) than marine records, which reflects both cooling and a source moisture compositional shift consistent with the growth of Antarctic ice. When combined with "clumped" isotope measurements from the same succession, about half of the isotopic shift can be attributed to cooling and about half to source moisture change, proportions similar to marine foraminiferal records. Thus, the new record indicates strong hydrological cycle connections between marine and marginal continental environments during the Eocene-Oligocene transition not observed in continental interior records.

†nsheldon@umich.edu

\section{INTRODUCTION}

The Eocene-Oligocene transition, onset at ca. $34 \mathrm{Ma}$, represents a climatic regime change from "greenhouse" conditions to "icehouse" conditions. Physical evidence (various; e.g., Davies et al., 2012) indicates the initiation of large-scale Antarctic glaciation during the Eocene-Oligocene transition, with permanent ice sheets formed on Antarctica for the first time between 34.0 and $33.65 \mathrm{Ma}$, peaking at the onset of an oxygen isotopic event known as Oi-1 (Miller et al., 1991; Zachos et al., 1996, 2001; Coxall et al., 2005; Pälike et al., 2006, supplement), which is an $\sim+1.1 \%$ o shift that reflects a combination of temperature and salinity/ ice-volume change (Zachos et al., 2008). Both benthic (Coxall et al., 2005; Coxall and Wilson, 2011) and planktonic (Pearson et al., 2008) foraminifera record a coherent spatial and temporal isotopic response, which implies globalscale changes to Earth's oceans and global-scale climatic cooling.

In contrast, continental records are spatially variable (Sheldon, 2009; Zanazzi et al., 2015), with regional differences in the magnitude of temperature change (e.g., Zanazzi et al., 2007 vs. Retallack, 2007), the magnitude of precipitation change (Sheldon and Retallack, 2004; Abels et al., 2011), and even whether precipitation increased or decreased (Sheldon et al., 2009). The widely recognized positive isotope excursion seen in marine foraminiferal $\delta^{18} \mathrm{O}$ records of the Eocene-Oligocene transition glaciation is rarely found in terrestrial records (cf. Zanazzi et al., 2007; Zanazzi and Kohn, 2008), which instead often show no discernible shift in $\delta^{18} \mathrm{O}$ (e.g., Sheldon et al., 2012) or a delayed shift relative to marine records (Zanazzi et al., 2007). In addition, it can be difficult to link marine and terrestrial records of the Eocene-Oligocene transition for two reasons: (1) Continental successions are most often preserved in endorheic basins, far from marine incursions that would make direct age comparison possible, and (2) oxygen isotope records from continental interiors can be complicated by a variety of non-temperaturerelated factors (e.g., changing circulation patterns, orographic effects) or may respond to local, rather than global hydrologic cycle drivers (e.g., Sheldon et al., 2012). Thus, sections in continental strata that span the EoceneOligocene transition and that are well calibrated to the geomagnetic polarity time scale and to marine geochronology are rare.

The English Hampshire Basin Solent Group (Fig. 1) was deposited in a coastal floodplain environment. It has documented magnetostratigraphy, sequence stratigraphy, mammalian and charophyte biostratigraphy, and brief calcareous nannoplankton events (Hooker, 1987, 2010; Sille et al., 2004; Gale et al., 2006; Hooker et al., 2009) that allow good calibration to marine records through the entire late Eocene (Priabonian) and early Oligocene (Rupelian). The depositional rate of the Solent Group strata is high, ranging from $\sim 3$ to $10 \mathrm{~cm}$ k.y. ${ }^{-1}$ (Hooker et al., 2009), which facilitates high-resolution sampling. The only significant hiatus was during the glacial maximum following the Oi-1 event, caused by major sea-level fall. Hren et al. (2013) recently published a "clumped isotope" paleotemperature reconstruction of the Eocene-Oligocene transition from the Solent Group based on the prosobranch gastropod Viviparus lentus (Solander), where they found: (1) the magnitude of mean annual air temperature change $\left(\sim 4-6{ }^{\circ} \mathrm{C}\right)$ was comparable to North Atlantic sea-surface 
Sheldon et al.
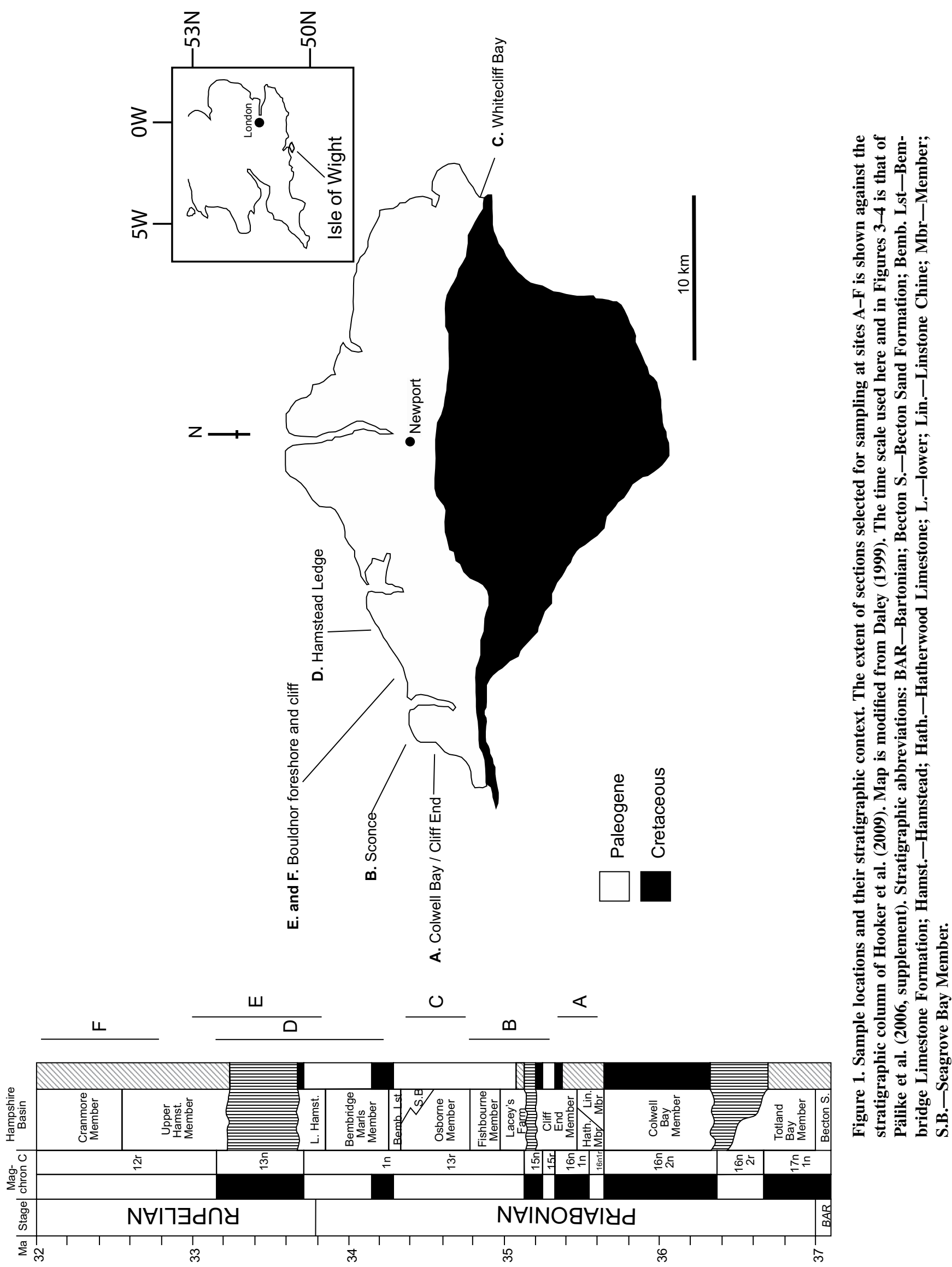
temperature changes, and (2) growing-season temperatures for $V$. lentus were essentially constant prior to the Eocene-Oligocene transition but dropped by nearly $10{ }^{\circ} \mathrm{C}$ following Oi-1. An earlier climate study of the Solent Group from the combined proxies of mammal tooth enamel, pulmonate gastropod (Lymnaea longiscata Brongniart) shells, fish otoliths, and charophyte gyrogonites at six horizons (Grimes et al., 2005) also found little evidence for variability in summer temperatures prior to the Eocene-Oligocene transition. However, both of those previous studies had limited data for the early Oligocene.

To build upon these low-resolution isotopederived climate studies and to provide greater data coverage for the early Oligocene, we analyzed the $\delta^{18} \mathrm{O}$ composition of shell carbonate of $V$. lentus at numerous horizons through 3 m.y. (35.4-32.4 Ma) of the Solent Group (Bugler, 2011). We then compared this new, denser paleoclimatic record (with $\sim 750$ k.y. leading up to Oi-1 having a frequency interval of $\sim 35$ k.y.) with marine oxygen isotope records and with paleoclimatic records from other continental Eocene-Oligocene transition sites (Fig. 2).

\section{SAMPLE LOCATIONS AND METHODOLOGY}

Six localities representing different parts of the late Eocene (Priabonian) to earliest Oligocene (Rupelian) Solent Group stratigraphy of the Hampshire Basin (Fig. 1; supplemental data and Table $\mathrm{S}^{1}$ ) were examined. In total, 40 stratigraphic horizons containing abundant shells of the freshwater prosobranch (gillbreathing) gastropod V. lentus were sampled, including both complete and fragmentary, but identifiable, shells. Modern Viviparus gastropods inhabit only clean, slowly moving or stable water bodies, and their habitat tracks the availability of aquatic environments (Boss, 1978). Fossil Viviparus gastropods have been used previously in studies of both warming (Schmitz and Andreasson, 2001) and cooling (Hren et al., 2013) Paleogene paleoclimate events, and modern Viviparus gastropod species reliably record changing environmental conditions (Bugler, 2011).

Bulk sediment samples were air dried, disaggregated in warm water, and then wet sieved

${ }^{1}$ GSA Data Repository item 2015314, supplemental information consists of: 1) GPS locations for sampling sites, 2) a supplemental table of isotopic data and 3) a supplemental table that summarizes paleoclimatic results from other continental sites, is available at http://www.geosociety.org/pubs/ft2015 .htm or by request to editing@geosociety.org.

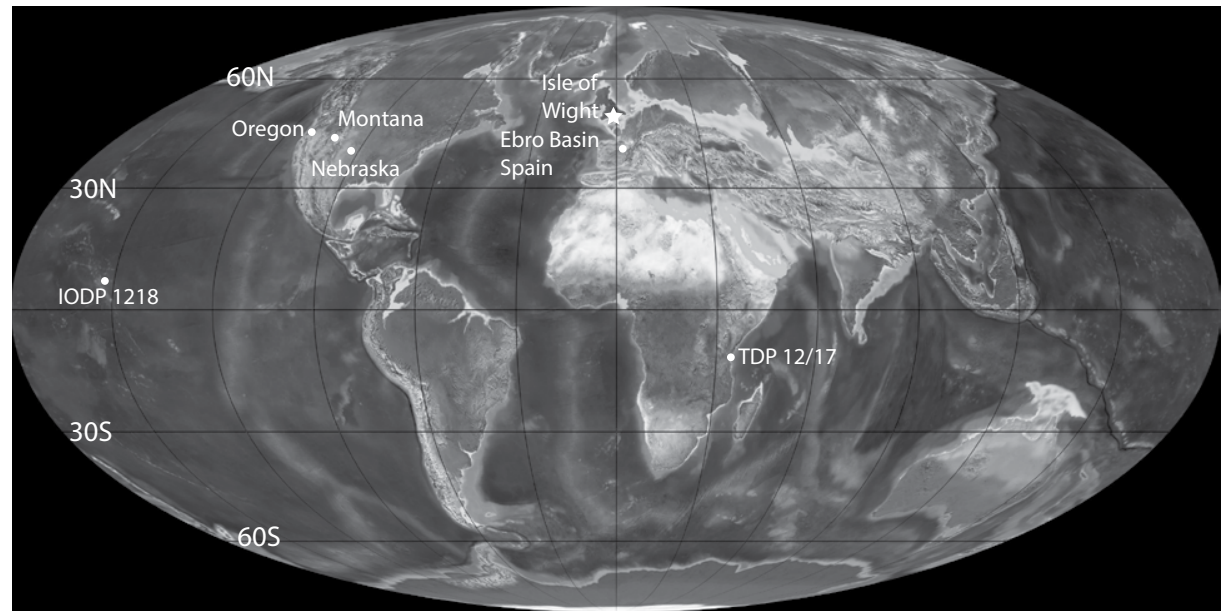

Figure 2. Locations of marine and terrestrial Eocene-Oligocene transition sites. Marine comparative sites include Integrated Ocean Drilling Project Site 1218 (IODP; e.g., Coxall et al., 2005) and Tanzanian Drilling Project Sites 12 and 17 (TDP; e.g., Pearson et al., 2008). North America terrestrial sites were reviewed in Sheldon (2009), and the Ebro Basin (Spain) site was described in Sheldon et al. (2012). Late Eocene paleogeographic base map is used with permission from Ron Blakey, Colorado Plateau Geosystems (original reference: Blakey, 2008).

using mesh sizes of $2 \mathrm{~mm}, 1 \mathrm{~mm}$, and $250 \mu \mathrm{m}$. Each size fraction was oven dried at $25{ }^{\circ} \mathrm{C}$. Between 7 and 15 randomly selected $V$. lentus fragments were picked from the $>2 \mathrm{~mm}$ size fraction and cleaned in an ultrasonic bath. Each individual fragment $(n=483)$ was crushed using an agate mortar and pestle. Between $0.30 \mathrm{mg}$ and $0.50 \mathrm{mg}$ aliquots of powder were placed into vials for isotope analysis. The remainder was retained for repeat analyses and X-ray diffraction (XRD) in order to check for any alteration of the original aragonite mineralogy.

To determine the preservation state of shells from individual horizons, powder from 3 to 5 $V$. lentus fragments from each horizon was analyzed either at Plymouth University or at Royal Holloway, University of London (RHUL). At Plymouth University, the samples were analyzed by Bugler, using a Phillips PW1792 X-ray diffractometer (XRD) with High-Score Plus identification software. The $V$. lentus powder was aligned along a metal plate, which was then placed into a sealed chamber within the XRD. A $\mathrm{Cu}$ anode source was used with generator settings of $30 \mathrm{kV}$ and $40 \mathrm{nA}$. Expert High Score was used to analyze the X-ray chromatography produced. At RHUL, samples were analyzed courtesy of Dr. Dave Alderton using a Philips Analytical XRD PW3710 machine with PC-APD diffraction software. Samples were scanned between $20^{\circ}$ to $50^{\circ}$ (20) using a copper tube anode.

For isotope analysis, the carbonate powders were reacted with $100 \%$ phosphoric acid at
$90{ }^{\circ} \mathrm{C}$ for $\sim 1 \mathrm{~h}$. The $\mathrm{CO}_{2}$ produced was analyzed on an Isoprime mass spectrometer with a Gilson multiflow carbonate auto-sampler at Plymouth University. The results were calibrated against Vienna Peedee belemnite (VPDB) using the international standards NBS-19, IAEA-CO-8, and IAEA-CO-9. Five NBS-19 standards were also evenly distributed throughout the individual isotope runs to correct for daily drift. The mean standard deviation on replicate analyses of individual samples was on the order of $0.2 \%$ for $\delta^{13} \mathrm{C}$ and $0.2 \%$ or for $\delta^{18} \mathrm{O}$. Analytical results are given in supplemental Table S1 (see footnote 1).

The lithostratigraphy used here (Figs. 1, 3, and 4) follows Hooker et al. (2009). Calibration of the Solent Group to the geomagnetic polarity scale (Vandenberghe et al., 2012) also follows Hooker et al. (2009), but the time scale used is that of Pälike et al. (2006, supplement). Calibration is based on combined biostratigraphy, magnetostratigraphy, and sequence stratigraphy, allowing for correlation between both terrestrial and marine records. The highest resolution was obtained where biostratigraphic events coincided with either sequence boundaries or magnetic polarity shifts, or both. Thus, in terms of samples used in this study, the most accurately positioned points are at the boundaries of normal and reversed polarity zones (where these are recorded), the base of the Lacey's Farm Member, the base of the Bembridge Limestone Formation, and top of the lower Hamstead Member. 
Geological Society of America Bulletin, published online on 14 September 2015 as doi:10.1130/B31315.1

Sheldon et al.
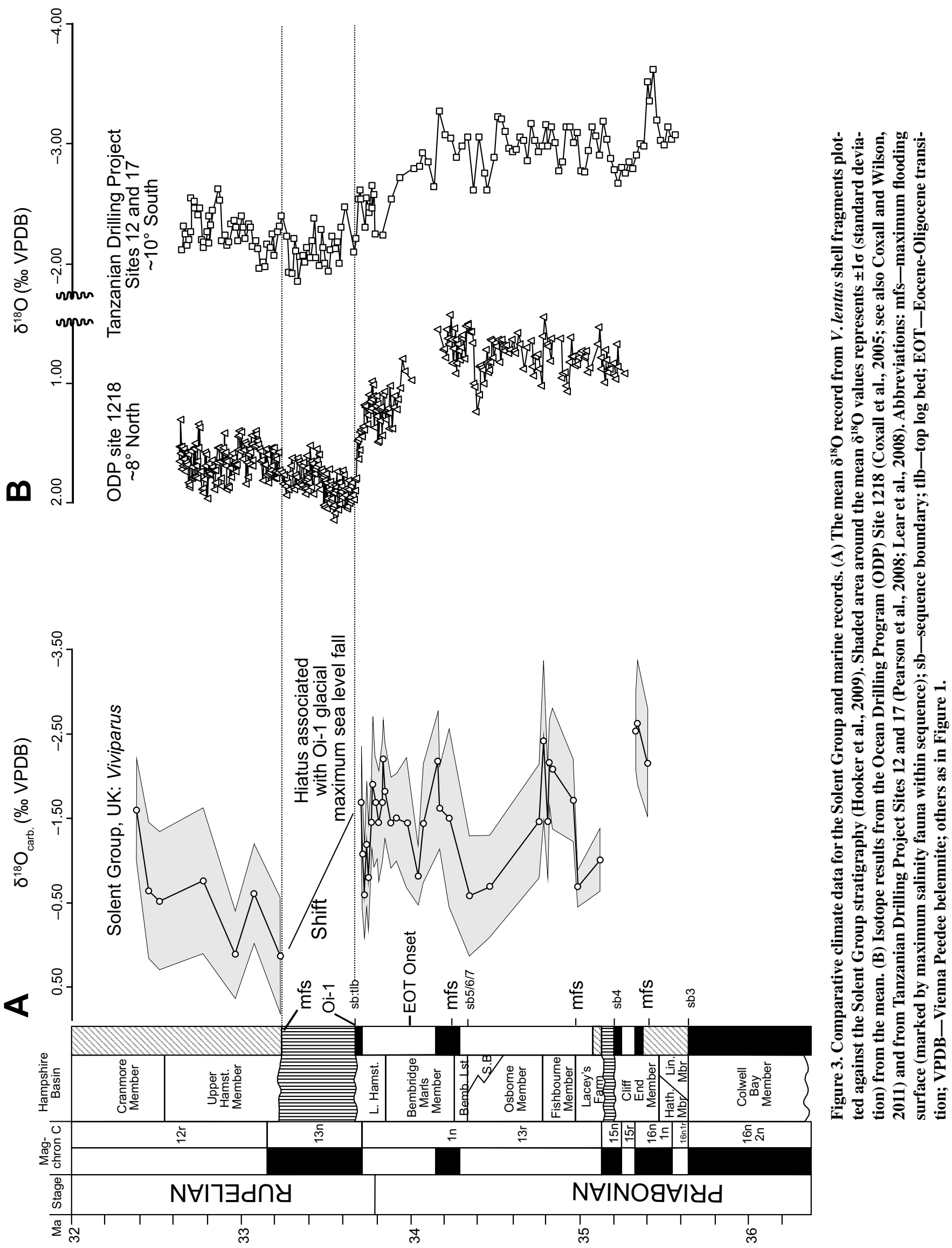
Geological Society of America Bulletin, published online on 14 September 2015 as doi:10.1130/B31315.1

Coupling of marine and continental oxygen isotope records during the Eocene-Oligocene transition

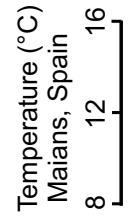

Ш

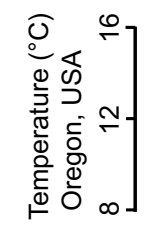

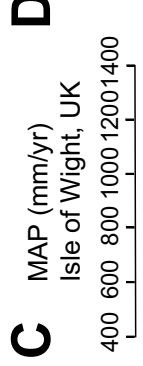

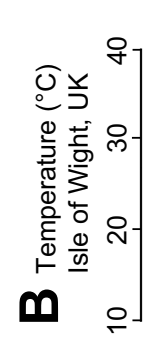

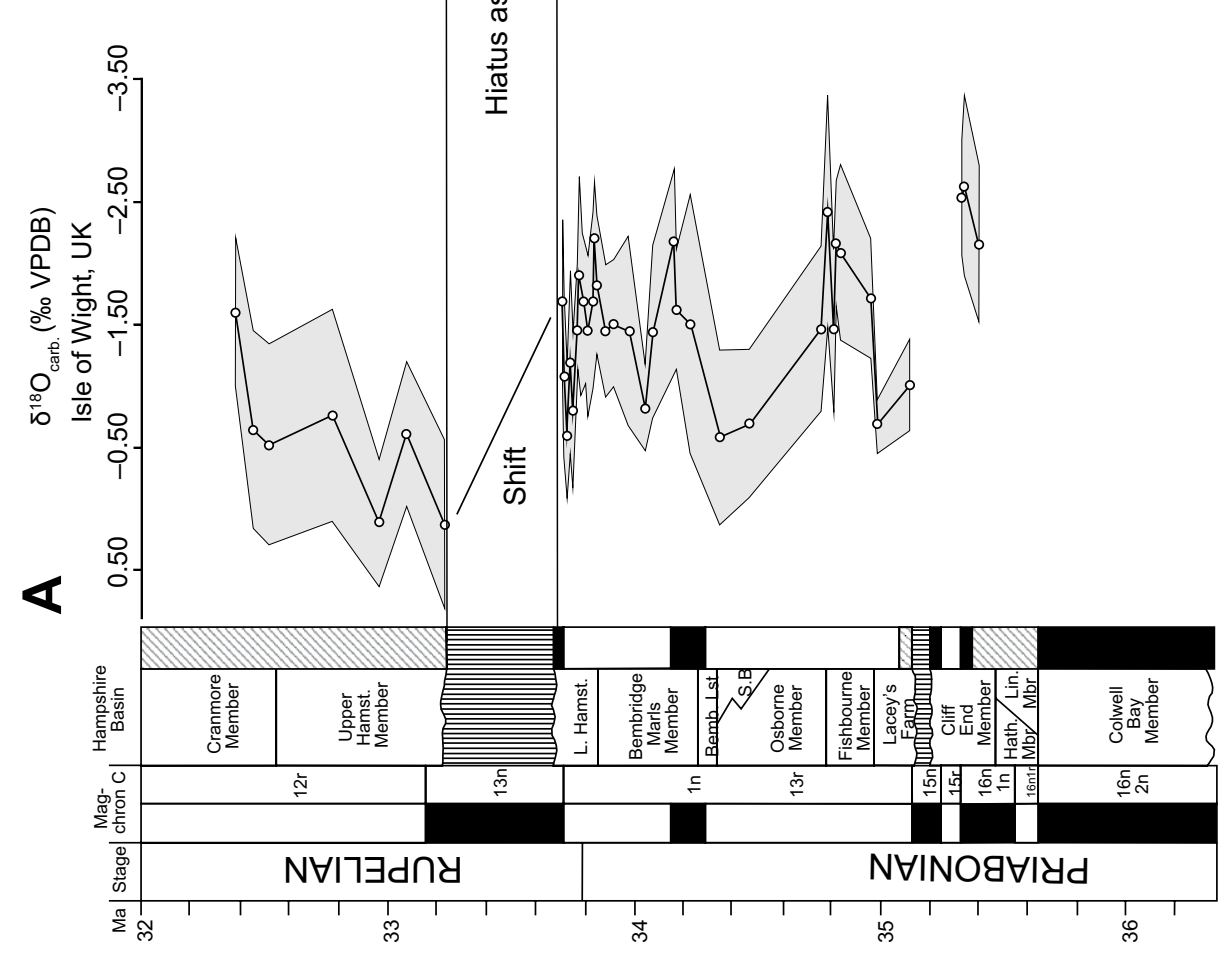

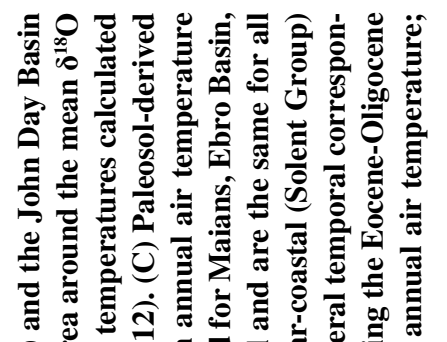

萡

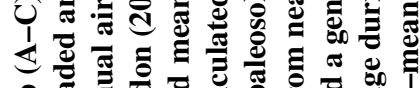

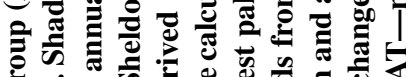

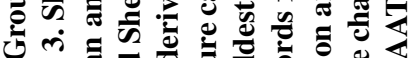

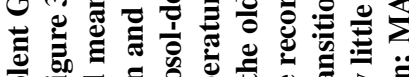

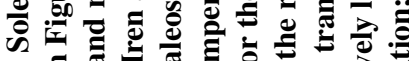

ป

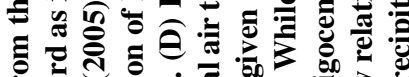

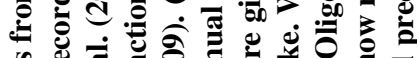

๘

\%

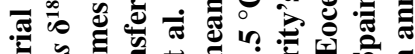

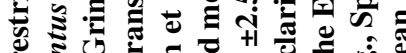

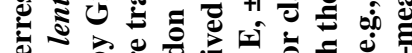

Ð

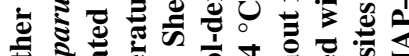

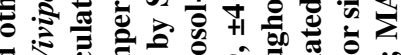

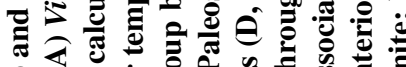

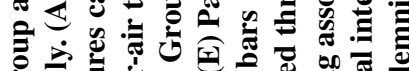

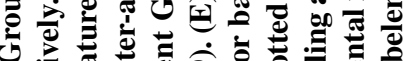

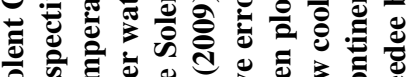

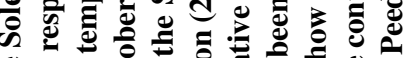

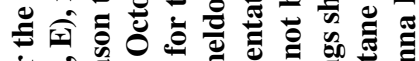

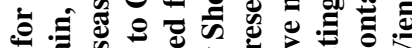

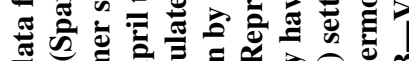

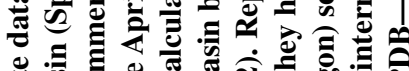

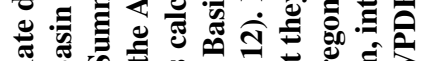

ถึ की

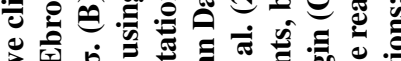

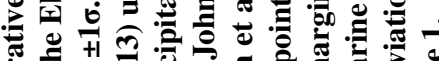

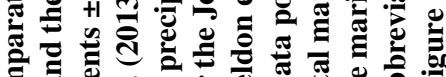

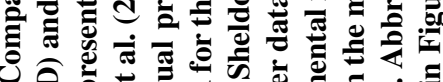

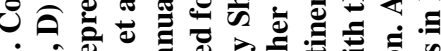

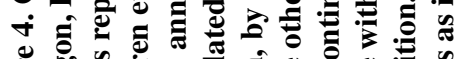

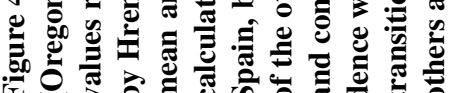


The hiatus during the Oi-1 glacial maximum is estimated as being the interval (Fig. 3) between the top log bed (tlb) sequence boundary and the subsequent maximum flooding surface of the Nematura bed (i.e., basal meter of the upper Hamstead Member; Hooker et al., 2009), identified as belonging to sequence TA4.4 of Haq et al. (1987). Between these points, resolution is less precise and assumes constant sedimentation rate. Sampling from the base of the Seagrove Bay Member to the top of the lower Hamstead Member, representing 750 k.y. (Eocene-Oligocene transition) leading up to Oi-1, averages a frequency interval of $\sim 35 \mathrm{k} . \mathrm{y}$. The sampling frequency in the last $\sim 250$ k.y. subset averages $\sim 18$ k.y.

\section{RESULTS}

XRD analyses of $173 \mathrm{~V}$. lentus fossil fragments from 40 horizons (22 spanning the Eocene-Oligocene transition and Oi-1) indicate preservation of aragonite consistent with that of another freshwater gastropod, L. longiscata, from the same clay-dominated lacustrine strata (Grimes et al., 2005). This, in addition to the preservation of three discrete carbonate layers, as viewed in numerous cross sections through representative shells (Bugler, 2011; Hren et al., 2013), strongly suggests that the $V$. lentus fossil fragments are not diagenetically recrystallized and therefore should preserve their original isotopic signal. These results are also supported by previous high-resolution single-shell microsampling that indicated that the $V$. lentus shells of the Solent Group preserve subannual seasonal variability in $\delta^{18} \mathrm{O}$ (Hren et al., 2013).

The $\delta^{18} \mathrm{O}$ record from $V$. lentus is shown in Figures 3 and 4 . At each of the 40 stratigraphic levels, the $\delta^{18} \mathrm{O}$ data points are a mean from the analyses of at least $7 \mathrm{~V}$. lentus shell fragments, and the associated errors (shaded region) are the standard deviation $( \pm 1 \sigma)$ from the mean. Bugler et al. (2009), based upon micromilled isotope profiles of a number of modern Viviparus contectus (Millet) shells, demonstrated that $\delta^{18} \mathrm{O}$ values could vary cyclically by up to $1.9 \%$, primarily as a response to changes in seasonal temperature. Similar-magnitude $\delta^{18} \mathrm{O}$ cycles were also shown by Hren et al. (2013) in a smaller number of whole $V$. lentus shells from the Solent Group, which suggests that the variability reported here from the analysis of multiple shell fragments is likely to be related to seasonal changes.

Early in the Eocene-Oligocene transition, $\delta^{18} \mathrm{O}$ values from $\mathrm{V}$. lentus shells are variable but generally cluster around $-1.5 \%$ (Figs. $3 \mathrm{~A}$ and 4A). Just prior to Oi-1 (upper half of the lower Hamstead Member), they shift to $-0.6 \%$ and then back to $-1.7 \%$ at $33.7 \mathrm{Ma}$. At Oi-1, $\delta^{18} \mathrm{O}$ values shift to $+0.1 \%$ o (basal upper Hamstead Member) before a gradual recovery toward more depleted values. The timings of these shifts are broadly similar to marine isotope records, with the Solent Group excursions and recoveries each roughly $0.5 \%$ larger than the marine isotope records. The pattern of a minor followed by a major positive shift resembles the succession Eocene-Oligocene transition 1 (precursor event) and Oi-1 in marine sites (e.g., Coxall et al., 2005; Coxall and Wilson, 2011; herein, Fig. 3B).

\section{DISCUSSION}

\section{Suitability of Using $V$. lentus as a Continental Oxygen Isotope Proxy}

Viviparus lentus, which has been used successfully before in paleoclimate research (Schmitz and Andreasson, 2001; Hren et al., 2013), is an ideal freshwater paleoclimate proxy because modern Viviparus species colonize a wide range of habitats, including rivers, streams, ponds, and lakes (Boss, 1978). They are also gill breathers (prosobranchs) and, therefore, are found in permanent water bodies up to $20 \mathrm{~m}$ deep (Boss, 1978). Their dependence on dissolved oxygen for respiration makes them intolerant of polluted water (Strayer, 1990), so they are rarely found in stagnant water bodies (e.g., shallow ponds; Jokinen, 1983), where significant evaporation can occur. These ecological parameters, in addition to evidence for the maintenance of primary aragonite and a three-layered shell structure, all suggest that the isotope record that has been generated from $V$. lentus is unaffected by diagenesis or evaporative enrichment.

\section{Factors Controlling Shifts in the V. lentus $\delta^{18} \mathrm{O}$ Record}

The magnitude of the $\delta^{18} \mathrm{O}$ shifts differs significantly between the continental $V$. lentus and the marine foraminiferal records. The marine $\delta^{18} \mathrm{O}$ shifts are typically of the order $0.4 \%$ $1.0 \%$, while those from the Hampshire Basin are $>1.4 \%$ (Fig. 3). Oxygen isotope values observed in the marine realm represent a combination of temperature and the oxygen isotopic composition of seawater, which is controlled mainly by changes in the global ice volume.

In the marine realm, a well-mixed ocean is assumed (various; e.g., Zachos et al., 2001), and, consequently, shifts in the oxygen isotopic composition of seawater are related largely or entirely to ice volume and temperature changes. While temperature plays a role in the continen- tal isotope record, the mechanisms that control the isotopic composition of the water source from which $V$. lentus precipitates are more complicated. These factors include (1) evaporation, (2) changes in the isotopic ratio of precipitation, and (3) change in sources of precipitation. These additional factors, the last two of which may be linked to changes in global ice volume, probably explain the greater magnitude of the isotope shifts seen in the continental realm.

In the previous section, an ecological argument against evaporation playing a dominant role in controlling the $V$. lentus $\delta^{18} \mathrm{O}$ record was presented. In other continental Eocene-Oligocene transition successions (Fig. 2), locally evaporative conditions are indicated by aridification (Sheldon and Retallack, 2004; Abels et al., 2011; Passchier et al., 2013; Boardman and Secord, 2013), by shifts in the assemblage of paleosol types (Terry, 2001), and by shifts in the trace fossil assemblage (Sheldon and Hamer, 2010). None of these features is observed in the Hampshire Basin, and rather than aridification through the Eocene-Oligocene transition, wetter conditions have been reconstructed (Fig. 4C; Sheldon et al., 2009) using the same reconstruction technique that indicated aridification in other regions (supplemental Table S2 [see footnote 1]). Furthermore, the most pronounced evidence for evaporative enrichment in the Hampshire Basin is at ca. $34.4 \mathrm{Ma}$, based on $\delta^{18} \mathrm{O}_{\text {water }}$ values calculated using clumped isotope data (Hren et al., 2013). In addition, some of the paleosols in the Hampshire Basin stratigraphic sequence also include various redoximorphic features such as drab-haloed root traces and rare $\mathrm{Fe}-\mathrm{Mn}$ nodules that are consistent with episodic or even continuous inundation (Sheldon et al., 2009). Thus, in contrast to some other continental records that are potentially compromised by local evaporative conditions (e.g., Nebraska; Sheldon, 2009; Boardman and Secord, 2013; cf. Zanazzi et al., 2015), the Hampshire Basin record appears likely to be a high-fidelity recorder of environmental conditions.

At the same time, if the $\delta^{18} \mathrm{O}$ shifts (Figs. 3A and $4 \mathrm{~A}$ ) were due to temperature change alone, then they are above, or at the very upper limit of, those previously recorded. For example, using the Viviparus genus-specific equation (Bugler et al., 2009), and assuming no change in the $\delta^{18} \mathrm{O}$ of freshwater, temperature shifts across the Eocene-Oligocene transition would be between $10{ }^{\circ} \mathrm{C}$ and $13{ }^{\circ} \mathrm{C}$. These reduce to $6-8{ }^{\circ} \mathrm{C}$ using a general inorganic aragonite equation (Grossman and $\mathrm{Ku}, 1986$ ) or if the likely season of the majority of carbonate formation is used to adjust the temperature (Hren and Sheldon, 2012). In contrast, a sea surface temperature (SST) change of $\sim 5^{\circ} \mathrm{C}$ across the Eocene- 
Oligocene transition has been reconstructed recently based on high-latitude marine records of $\mathrm{TEX}_{86}$ (tetraether index of tetraethers consisting of 86 carbon atoms) and $\mathrm{U}_{37}^{\mathrm{K}^{\prime}}$ (unsaturation index of $\mathrm{C}_{37}$ alkenones; Liu et al., 2009). Similarly, Hren et al. (2013) documented a $4-6{ }^{\circ} \mathrm{C}$ drop in mean annual air temperature across the Eocene-Oligocene transition (Fig. 4B) using $V$. lentus as in this study, and "clumped isotope" analyses, which are insensitive to evaporation or to changes in source-water $\delta^{18} \mathrm{O}$. Thus, the discrepancy between the apparent magnitude of temperature change indicated by the new $\delta^{18} \mathrm{O}$ record if due to temperature alone $\left(6-13{ }^{\circ} \mathrm{C}\right.$, depending on equation) and the "clumped isotope" record $\left(4-6{ }^{\circ} \mathrm{C}\right)$ likely indicates a shift in source-water $\delta^{18} \mathrm{O}$ toward relatively enriched values, which accompanied the drop in temperature. Because source-water evaporative enrichment was unlikely to have been significant (see earlier herein), the shift in sourcewater $\delta^{18} \mathrm{O}$ toward enriched values instead likely records enrichment in meteoric water due to ice-sheet growth on Antarctica. Assuming that the "clumped isotope" record (Hren et al., 2013) and high-latitude marine SST record (Liu et al., 2009) reflect the "true" temperature change, then roughly half of the $\delta^{18} \mathrm{O}$ shift recorded in the new Hampshire Basin V. lentus record is due to temperature change, and half is due to ice-volume change. These relative proportions are similar to what has been inferred for marine foraminiferal $\delta^{18} \mathrm{O}$ records (Zachos et al., 2001; Coxall et al., 2005; Gallagher and Sheldon, 2013). In addition, the marine SST (Liu et al., 2009) and "clumped isotope" records (Fig. 4B) both indicate a post-Eocene-Oligocene transition rebound to slightly warmer conditions that is mirrored by marine $\delta^{18} \mathrm{O}$ records and by the Hampshire Basin V. lentus $\delta^{18} \mathrm{O}$ record (Figs. $3 \mathrm{~A}$ and $4 \mathrm{~A}$ ), and by reconstructed atmospheric $p \mathrm{CO}_{2}$ based on the $\delta^{11} \mathrm{~B}$ composition of planktonic foraminifera (Pearson et al., 2009).

Additional support for interpretation of the enriched $\delta^{18} \mathrm{O}$ values during the Eocene-Oligocene transition and Oi-1 as representing both ice volume and temperature is provided by sequence stratigraphy. The highest $\delta^{18} \mathrm{O}$ values and lowest clumped isotope temperatures postdate the top log bed (tlb) sequence boundary (Fig. 3), where an unconformity indicates major sea-level fall. In contrast, lower in the succession, pre-EoceneOligocene transition (Fig. 3A), high $\delta^{18} \mathrm{O}$ values coincide with sequence boundaries (Lacey's Farm and Seagrove Bay Members), while shifts toward lower values coincide with maximum flooding surfaces (Fishbourne and Bembridge Marls Members), where temperatures recorded by clumped isotopes are relatively stable (Fig. $4 \mathrm{~B})$. This suggests that changes in ice volume, not temperature, were responsible for the $\delta^{18} \mathrm{O}$ peaks and troughs during the $\sim 1$ m.y. preceding the Eocene-Oligocene transition.

Observations of modern $V$. contectus in England indicate that shell growth is dominated by summer growth (Bugler et al., 2009). Ecology of $V$. lentus preserved in the Hampshire Basin was likely similar, even if the overall climate state was warmer during the EoceneOligocene transition. Lake water temperatures are very highly correlated with air temperatures, but the precise relationship varies quantitatively according to latitude and also to the length of season that is considered (Hren and Sheldon, 2012). Thus, while it is difficult to ascertain exactly what part of the year is represented by the Hampshire Basin record, it is likely most reflective of summer growing-season lake conditions. Serial isotope sampling of $V$. lentus from the Hampshire Basin indicates similar season ranges before, during, and after the Eocene-Oligocene transition, but with different absolute values during the Eocene-Oligocene transition, suggesting substantial reorganization of the hydrologic cycle (Bugler, 2011; Hren et al., 2013). While the large sustained $\delta^{18} \mathrm{O}$ shift recorded in the Hampshire Basin is not recorded in European endorheic basin records (Maians, Spain; Fig. 4D), similar reorganization of the hydrologic cycle was previously identified from high-magnitude variability in paleosol carbonate $\delta^{18} \mathrm{O}$ values (Sheldon et al., 2012). Because the poles cooled more rapidly during the Eocene-Oligocene transition than lower-latitude sites (e.g., Liu et al., 2009), the changing ocean and air temperature gradients may have changed the moisture source amounts more at higher latitudes as well. Although records from other sites are needed to confirm this pattern, it suggests that ice-sheet growth on Antarctica was connected to Northern Hemisphere climate through cooling of North Atlantic Ocean waters and alteration of regional hydrology.

\section{Comparison with Other Terrestrial Paleoclimate Records}

As discussed in the introduction, terrestrial records of the Eocene-Oligocene transition indicate varied responses and varied magnitudes of response (supplemental Table S2 [see footnote 1]; Fig. 4). For example, records from the Hampshire Basin (this study; Hren et al., 2013), Nebraska (Zanazzi et al., 2007; but see also Boardman and Secord, 2013), and Oregon (Sheldon and Retallack, 2004; Gallagher and Sheldon, 2013) indicate significant cooling, while records from Montana (Retallack, 2007) and Spain (Sheldon et al., 2012) indicate little or no cooling. There are no systematic differences between the type of proxy employed (i.e., paleosol records can indicate either cooling or stability, depending on the locality), which suggests that this environmental heterogeneity is real. Summarizing from various studies, two general trends have emerged: (1) Proximity to a marine moisture source matters, and (2) the magnitude of climatic response is larger at higher paleolatitudes. In comparing a number of paleoprecipitation reconstructions, Sheldon et al. (2012) recognized that records from endorheic basins indicated little response, whereas basins that were exorheic and located close to their marine moisture source (e.g., Hampshire Basin) recorded a strong response. This is similar to the observation that modern coastal precipitation stations record $\delta^{18} \mathrm{O}$ of precipitation that more closely mirrors changes in surface ocean water $\delta^{18} \mathrm{O}$ than inland sites, due to continentality effects (Dansgaard, 1964). Similarly, terrestrial temperature response to the EoceneOligocene transition (Fig. 4) appears to reflect paleolatitude, where higher-paleolatitude sites (Fig. 2; e.g., Hampshire Basin; Blakey, 2008) indicate higher-magnitude cooling as compared to relatively lower-paleolatitude sites (e.g., Oregon), a pattern which mimics marine SST records (Liu et al., 2009). Thus, when combining both patterns, a midlatitude endorheic basin site such as the Ebro Basin (Fig. 4E; Sheldon et al., 2012) shows little or no climatic response to the Eocene-Oligocene transition, whereas a higher-latitude coastal plain site such as the Isle of Wight (Figs. 4A and 4B; this study) records the highest-magnitude changes, larger even than other sites located relatively close to the ocean (e.g., Oregon). In Oregon, the Cascades uplift postdated the Eocene-Oligocene transition and causes a rain shadow at present that was not a factor in the Paleogene. Furthermore, accretion of the Coast Range generally postdates the Eocene, so central Oregon was much closer to the coastline at the time of deposition than it is at present (Fig. 2).

\section{CONCLUSIONS}

XRD data, shell structural preservation, and ecology of nearest living relatives suggest that $V$. lentus from the UK Solent Group yields a $\delta^{18} \mathrm{O}$ record that has not been affected by diagenesis. Based on paleosol proxy evidence, precipitation increases up sequence and does not shift in amount in parallel with the $V$. lentus $\delta^{18} \mathrm{O}$ record, further indicating that evaporation is unlikely to be a major factor affecting these continental oxygen isotope values in the Solent Group during the Eocene-Oligocene transition.

The oxygen isotope record derived from $V$. lentus records a positive $\delta^{18} \mathrm{O}$ shift across 
Oi- 1 of $>1.4 \%$ o that is roughly coincident with marine foraminiferal records. If entirely due to temperature, this would equate to a highmagnitude cooling, contrasting with marine SST from roughly the same paleolatitude and continental "clumped isotope" records from the same site. This implies a contribution to the $\delta^{18} \mathrm{O}$ shift from another factor, such as changes in the isotopic composition of the meteoric water in which $V$. lentus grew. The most likely cause of this change, supported by coincidence with sea-level fall, is the growth of ice sheets on Antarctica, which would have shifted marine source waters toward more-enriched $\delta^{18} \mathrm{O}$ values. Thus, while the magnitude of the total $\delta^{18} \mathrm{O}$ shift recorded in the Hampshire Basin is larger than in marine records, the relative contribution of temperature and ice-volume changes appears to be the same. This, coupled with comparison of continental sites that are more distal relative to marine moisture sources and at other paleolatitudes, indicates strong terrestrial-marine coupling during the Eocene-Oligocene transition via the global hydrological cycle and provides a possible explanation for the observed spatial heterogeneity of terrestrial EoceneOligocene transition responses.

\section{ACKNOWLEDGMENTS}

We would like to thank Plymouth University for funding a Ph.D. studentship (Bugler), the National Trust and Mr. and Mrs. Cool for access to sampling sites, the University of Michigan's Turner Postdoctoral Fellowship (to Hren), and Dave Alderton from Royal Holloway University of London for assistance with $\mathrm{X}$-ray diffraction analysis. Associate Editor Brian Pratt and reviewers Lee Nordt and Karlis Muehlenbachs are all thanked for their constructive reviews, which have improved the final manuscript.

\section{REFERENCES CITED}

Abels, H.A., Dupont-Niven, G., Xiao, G.Q., Bosboom, R., and Krijsman, W., 2011, Step-wise change of Asian interior climate preceding the Eocene-Oligocene transition (EOT): Palaeogeography, Palaeoclimatology, Palaeoecology, v. 299, p. 399-412, doi:10.1016/j .palaeo.2010.11.028

Blakey, R.C., 2008, Gondwana paleogeography from assembly to breakup-A 500 m.y. odyssey, in Fielding, C.R., Frank, T.D., and Isbell, J.L., eds., Resolving the Late Paleozoic Ice Age in Time and Space: Geological Society of America Special Paper 441, p. 1-28, doi:10 $.1130 / 2008.2441(01)$

Boardman, G.S., and Secord, R., 2013, Stable isotope paleoecology of White River ungulates during the Eocene-Oligocene climate transition in northwestern Nebraska: Palaeogeography, Palaeoclimatology, Palaeoecology, v. 375 , p. $38-49$, doi:10.1016/j.palaeo 2013.02.010

Boss, K.J., 1978, On the evolution of gastropods in ancient lakes, in Fretter, V., and Peake, J., eds., Pulmonates: Systematics, Evolution and Ecology, Volume 2A: London, Academic Press, p. 385-428.

Bugler, M.J., 2011, An Investigation into the Use of the Freshwater Gastropod Viviparus as a Recorder of Past Climate Change [Ph.D. thesis]: Plymouth, UK, Plymouth University.
Bugler, M.J., Grimes, S.T., Leng, M.J., Rundle, S.D., Price, G.D., Hooker, J.J., and Collinson, M.E., 2009, Experimental determination of a Viviparus contectus thermometry equation: Rapid Communications in Mass Spectrometry, v. 23 , p. 2939-2951, doi:10.1002/rcm .4203 .

Coxall, H.K., and Wilson, P.A., 2011, Early Oligocene glaciation and productivity in the eastern equatorial Pacific: Insights into global carbon cycling: Paleoceanography, v. 26, PA2221, doi:10.1029/2010PA002021.

Coxall, H.K., Wilson, P.A., Palike, H., Lear, C.H., and Backman, J., 2005, Rapid stepwise onset of Antarctic glaciation and deeper calcite compensation in the Pacific Ocean: Nature, v. 433, p. 53-57, doi:10.1038 /nature 03135 .

Daley, B., 1999, Palaeogene sections in the Isle of Wight: A revision of their description and significance in the light of research undertaken over recent decades: Tertiary Research, v. 19, p. 1-60.

Dansgaard, W., 1964, Stable isotopes in precipitation: Tellus, v. 16, p. 436-468.

Davies, B.J., Hambrey, M.J., Smellie, J.L., Carrivick, J.L., and Glasser, N.F., 2012, Antarctic Peninsula ice sheet evolution during the Cenozoic Era: Quaternary Science Reviews, v. 31, p. 30-66.

Gale, A.S., Huggett, J.M., Pälike, H., Laurie, E., Hailwood, E.A., and Hardenbol, J., 2006, Correlation of EoceneOligocene marine and continental records: Orbital cyclicity, magnetostratigraphy and sequence stratigraphy of the Solent Group, Isle of Wight, UK: Journal of the Geological Society of London, v. 163, p. 401-415, doi:10.1144/0016-764903-175.

Gallagher, T.M., and Sheldon, N.D., 2013, A new paleothermometer for forest paleosols and its implications for Cenozoic climate: Geology, v. 41, p. 647-650.

Grimes, S.T., Hooker, J.J., Collinson, M.E., and Mattey, D.P., 2005, Temperatures of late Eocene to early Oligocene freshwaters: Geology, v. 33, p. 189-192, doi:10 $.1130 / \mathrm{G} 21019.1$.

Grossman, E.L., and Ku, T.L., 1986, Oxygen and carbon isotope fractionation in biogenic aragonite-Temperature effects: Chemical Geology, v. 59, p. 59-74, doi:10 .1016/0168-9622(86)90057-6.

Haq, B.U., Hardenbol, J., and Vail, P.R., 1987, Chronology of fluctuating sea levels since the Triassic: Science, v. 235 , p. $1156-1167$, doi:10.1126/science. 235.4793 .1156 .

Hooker, J.J. 1987, Mammalian faunal events in the English Hampshire Basin (late Eocene-early Oligocene) and their application to European biostratigraphy: Münchner Geowissenschaftlicher Abhandlungen, v. A10, p. 109-116.

Hooker, J.J., 2010, The 'Grande Coupure' in the Hampshire Basin, UK: Taxonomy and stratigraphy of the mammals on either side of this major Palaeogene faunal turnover, in Whitaker, J.E., and Hart, M.B., eds., Micropalaeontology, Sedimentary Environments and Stratigraphy: A Tribute to Dennis Curry (1912-2001): The Micropalaeontological Society Special Publication 4, p. 147-215

Hooker, J.J., Grimes, S.T., Mattey, D.P., Collinson, M.E., and Sheldon, N.D., 2009, Refined correlation of the UK late Eocene-early Oligocene Solent Group and timing of its climate history, in Koeberl, C., and Montanari, A., eds., The Late Eocene Earth-Hothouse, Icehouse, and Impacts: Geological Society of America Special Paper 452, p. 179-195.

Hren, M.T., and Sheldon, N.D., 2012, Temporal variations in lake water temperature: Paleoenvironmental implications of lake carbonate $\delta^{18} \mathrm{O}$ and temperature records: Earth and Planetary Science Letters, v. 337-338, p. 77-84, doi:10.1016/j.epsl.2012.05.019

Hren, M.T., Sheldon, N.D., Bugler, M.J., Grimes, S.T., Hooker, J.J., Collinson, M.E., and Lohmann, K.C., 2013, Terrestrial cooling in northern Europe during the Eocene-Oligocene transition: Proceedings of the National Academy of Sciences of the United States of America, v. 110, p. 7562-7567, doi:10.1073/pnas 1210930110 .

Jokinen, E., 1983, The freshwater snail (Mollusca: Gastropoda) of New York State: New York State Museum Bulletin, v. 482, p. 1-112.
Lear, C.H., Bailey, T.R., Pearson, P.N., Coxall, H.K., and Rosenthal, Y., 2008, Cooling and ice growth across the Eocene-Oligocene transition: Geology, v. 36 p. 251-254.

Liu, Z., Pagani, M., Zinniker, D., DeConto, R., Huber, M., Brinkhuis, H., Shah, S.R., Leckie, R.M., and Pearson, A., 2009, Global cooling during the Eocene-Oligocene climate transition: Science, v. 323, p. 1187-1190, doi: 10.1126/science. 1166368

Miller, K.G., Wright, J.D., and Fairbanks, R.G., 1991, Unlocking the ice house-Oligocene/Miocene oxygen isotopes, eustasy and margin erosion: Journal of Geophysical Research-Solid Earth and Planets, v. 96 p. 6829-6848, doi:10.1029/90JB02015.

Pälike, H., Norris, R.D., Herrle, J.O., Wilson, P.A., Coxall, H.K., Lear, C.H., Shackleton, N.J., Tripati, A.K., and Wade, B.S., 2006, The heartbeat of the Oligocene climate system: Science, v. 314, p. 1894-1898, doi:10 $.1126 /$ science. 1133822 .

Passchier, S., Bohaty, S.M., Jiménez-Espejo, F., Pross, J., Röhl, U., van de Flierdt, T., Escutia, C., and Brinkhuis, H., 2013, Early Eocene-to-middle Miocene cooling and aridification of East Antarctica: Geochemistry Geophysics Geosystems, v. 14, p. 1399-1410, doi:10 $.1002 /$ ggge.20106.

Pearson, P.N., Foster, G.L., and Wade, B.S., 2009, Atmospheric carbon dioxide through the Eocene-Oligocene transition: Nature, v. 461 , p. $1110-1113$, doi:10.1038 /nature08447.

Pearson, P.N., McMillan, I.K., Wade, B.S., Dunkley Jones, T., Coxall, H.K., Bown, P.R., and Lear, C.H., 2008, Extinction and environmental change across the Eocene-Oligocene boundary in Tanzania: Geology, v. 36, p. 179-182, doi:10.1130/G24308A.1.

Retallack, G.J., 2007, Cenozoic paleoclimate on land in North America: The Journal of Geology, v. 115 p. 271-294, doi:10.1086/512753.

Schmitz, B., and Andreasson, F.P., 2001, Air humidity and lake delta O-18 during the latest Paleocene-earliest Eocene in France from recent and fossil fresh-water and marine gastropod $\delta^{18} \mathrm{O}, \delta^{13} \mathrm{C}$, and ${ }^{87} \mathrm{Sr} /{ }^{86} \mathrm{Sr}$ : Geological Society of America Bulletin, v. 113, p. 774-789, doi: 10.1130/0016-7606(2001)113<0774:AHALOD>2.0 .CO;2

Sheldon, N.D., 2009, Nonmarine records of climatic change across the Eocene-Oligocene transition, in Koeberl, C., and Montanari, A., eds., The Late Eocene Earth-Hothouse, Icehouse, and Impacts: Geological Society of America Special Paper 452, p. 241-248.

Sheldon, N.D., and Hamer, J.M.M., 2010, Evidence for an early sagebrush ecosystem in the latest Eocene of Montana: The Journal of Geology, v. 118, p. 435-445, doi: $10.1086 / 652660$.

Sheldon, N.D., and Retallack, G.J., 2004, Regional precipitation records from the late Eocene and early Oligocene of North America: The Journal of Geology, v. 112 , p. $487-494$, doi:10.1086/421076.

Sheldon, N.D., Mitchell, R.L., Collinson, M.E., and Hooker, J.J., 2009, Eocene-Oligocene transition paleoclimatic and paleoenvironmental record from the Isle of Wight in Koeberl, C., and Montanari, A., eds., The Late Eocene Earth-Hothouse, Icehouse, and Impacts: Geological Society of America Special Paper 452, p. 249-259.

Sheldon, N.D., Costa, E., Cabrera, L., and Garcés, M., 2012 Continental climatic and weathering response to the Eocene-Oligocene transition: The Journal of Geology, v. 120 , p. $227-236$, doi: $10.1086 / 663984$

Sille, N.P., Collinson, M.E., Kucera, M., and Hooker, J.J., 2004, Evolution within the charophyte genus Harrisichara, late Paleogene, southern England; environmental and biostratigraphic implications: Palaeogeography, Palaeoclimatology, Palaeoecology, v. 208, p. 151-171, doi:10.1016/j.palaeo.2004 .03 .002 .

Strayer, D., 1990, Freshwater Mollusca, in Peckarsky, B.L., Frassinet, P.R., Penton, M.A., and Conklin, D.J., eds., Freshwater Macroinvertebrates of Northeastern North America: New York, Cornell University Press, p. 335-372.

Terry, D.O., 2001, Paleopedology of the Chadron Formation, northwestern Nebraska: Implications for paleo- 
Geological Society of America Bulletin, published online on 14 September 2015 as doi:10.1130/B31315.1

Coupling of marine and continental oxygen isotope records during the Eocene-Oligocene transition

climate in the North American mid-continent across the Eocene-Oligocene boundary: Palaeogeography, Palaeoclimatology, Palaeoecology, v. 168, p. 1-38, doi 10.1016/S0031-0182(00)00248-0.

Vandenberghe, N., Hilgen, F.G., Speijer, R.P., Ogg, J.G., Gradstein, F.M., Hammer, O., Hollis, C.J., and Hooker, J.J., 2012, The Paleogene Period, in Gradstein, F.M. Ogg, J.G., Schmitz, M., and Ogg, G., eds., The Geologic Time Scale 2012: Oxford, UK, Elsevier, p. 855-921.

Zachos, J.C., Quinn, T.M., and Salamy, K.A., 1996, Highresolution $\left(10^{4}\right.$ years $)$ deep-sea foraminiferal stable isotope records of the Eocene-Oligocene climate transition: Paleoceanography, v. 11, p. 251-266, doi:10 .1029/96PA00571.
Zachos, J.C., Pagani, M., Sloan, L., Thomas, E., and Billups, K., 2001, Trends, rhythms, and aberrations in global climate 65 Ma to present: Science, v. 292, p. 686-693, doi:10.1126/science.1059412.

Zachos, J.C., Dickens, G.R., and Zeebe, R.E., 2008, An early Cenozoic perspective on greenhouse warming and carbon-cycle dynamics: Nature, v. 451, p. 279-283, doi: 10.1038 /nature06588.

Zanazzi, A., and Kohn, M.J., 2008, Ecology and physiology of White River mammals based on stable isotope ratios of teeth: Palaeogeography, Palaeoclimatology, Palaeoecology, v. 257, p. 22-37, doi:10.1016/j.palaeo .2007.08.007.

Zanazzi, A., Kohn, M.J., MacFadden, B.J., and Terry, D.O., 2007, Large temperature drop across the Eocene-
Oligocene transition in central North America: Nature, v. 445 , p. $639-642$.

Zanazzi, A., Judd, E., Fletcher, A., Bryant, H., and Kohn, M.J., 2015, Eocene-Oligocene latitudinal climate gradients in North America inferred from stable isotope ratios in perissodactyl tooth enamel: Palaeogeography, Palaeoclimatology, Palaeoecology, v. 417, p. 561-568, doi:10.1016/j.palaeo.2014.10.024.

Science Editor: Aaron Cavosie Associate Editor: Brian R. Prat

Manuscript Received 6 March 2015 Revised Manuscript Received 17 June 2015 Manuscript AcCePted 26 August 2015

Printed in the USA 


\section{Geological Society of America Bulletin}

\section{Coupling of marine and continental oxygen isotope records during the Eocene-Oligocene transition}

Nathan D. Sheldon, Stephen T. Grimes, Jerry J. Hooker, Margaret E. Collinson, Melanie J. Bugler, Michael T. Hren, Gregory D. Price and Paul A. Sutton

Geological Society of America Bulletin published online 14 September 2015; doi: 10.1130/B31315.1

\section{Email alerting services}

Subscribe

Permission request click www.gsapubs.org/cgi/alerts to receive free e-mail alerts when new articles cite this article

click www.gsapubs.org/subscriptions/ to subscribe to Geological Society of America Bulletin

click http://www.geosociety.org/pubs/copyrt.htm\#gsa to contact GSA

Copyright not claimed on content prepared wholly by U.S. government employees within scope of their employment. Individual scientists are hereby granted permission, without fees or further requests to GSA, to use a single figure, a single table, and/or a brief paragraph of text in subsequent works and to make unlimited copies of items in GSA's journals for noncommercial use in classrooms to further education and science. This file may not be posted to any Web site, but authors may post the abstracts only of their articles on their own or their organization's Web site providing the posting includes a reference to the article's full citation. GSA provides this and other forums for the presentation of diverse opinions and positions by scientists worldwide, regardless of their race, citizenship, gender, religion, or political viewpoint. Opinions presented in this publication do not reflect official positions of the Society.

\section{Notes}

Advance online articles have been peer reviewed and accepted for publication but have not yet appeared in the paper journal (edited, typeset versions may be posted when available prior to final publication). Advance online articles are citable and establish publication priority; they are indexed by GeoRef from initial publication. Citations to Advance online articles must include the digital object identifier (DOIs) and date of initial publication.

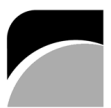

THE GEOLOGICAL SOCIETY OF AMERICA 